\title{
Crime concentration at micro-places in Latin America
}

\author{
Spencer P. Chainey ${ }^{1 *} \mathbb{0}$, Gastón Pezzuchi ${ }^{2}$, Néstor Octavio Guerrero Rojas ${ }^{3}$, José Luis Hernandez Ramirez ${ }^{3}$, \\ Joana Monteiro ${ }^{4}$ and Erwin Rosas Valdez ${ }^{1}$
}

\begin{abstract}
Research on crime concentration at micro-places has had a very western-industrialised focus. In this paper we provide results on crime concentration for 42 cities in Latin America. The results suggest that crime is concentrated at higher levels in Latin American cities than in western-industrialised contexts. Reasons for this do not appear to be related to population size, average street length, numbers of crimes or crime rates. The results offer an indication of the crime reduction opportunities that could come from the implementation of programs that are precisely targeted to the micro-places where crime has been observed to highly concentrate, such as hot spot policing.
\end{abstract}

Keywords: Crime concentration, Micro-places, Latin America

\section{Introduction}

Academic study into the geography of crime has increasing been oriented to examining crime at micro-places (Weisburd 2015). To date research on this topic has largely omitted any examination of crime concentration in the important crime research region of Latin America where crime levels are many times greater than those experienced in western-industrialised contexts (UNODC 2018). For example, in a systematic review of more than 45 studies of crime concentration (Lee et al. 2017) no studies from Latin America were included. For crime concentration research to effectively advance, be universally applicable and of wide practical relevance, examining patterns of crime is essential in environments where the settings are often different to the environments where this research topic has emerged.

In this paper we provide a contribution to the spatial crime concentration literature (see Braga et al. 2017 for a detailed review) by examining crime concentration levels in Argentina, Brazil, Colombia, Mexico, Uruguay, and Venezuela. We hypothesise that crime is highly concentrated in Latin American urban contexts.

\footnotetext{
*Correspondence: s.chainey@ucl.ac.uk

${ }^{1}$ Department of Security and Crime Science, University College London,

35 Tavistock Square, London WC1H 9EZ, England, UK

Full list of author information is available at the end of the article
}

\section{Methods and data}

Geocoded crime data at the street segment level for a 1-year period (for 2017 unless otherwise stated) from 37 cities in Latin America were used in the current study. These cities were selected due to ease of access to data, good procedures for recording crime data and their independent assessment (Chainey and Monteiro 2019; Fórum Brasileiro de Segurança Pública 2011). The analysis was performed on homicide, robbery, theft from the person, vehicle theft and other theft. Data on particular crime types for each city were selected based on consistency in definition, and use from in-house analysis to help inform new police interventions. In each case, the geocoding hit rate was above the $85 \%$ minimum threshold for reliability suggested by Ratcliffe (2004). Results from five additional cities from two other studies (Jaitman and Ajzenman 2016; Mejía et al. 2015) were included for further completeness.

Weisburd (2015) states that crime concentrates amongst street segments within certain spatial bandwidths: for a cumulative proportion of $25 \%$ of crime, the bandwidth for the proportion of micro-places is between 0.4 and $1.6 \%$; and for a cumulative proportion of $50 \%$ of crime, the bandwidth for the proportion of micro-places is between 2.1 and $6 \%$. Whilst other methods for measuring crime concentration exist [e.g., Lorenz curves and Gini coefficients (Bernasco and Steenbeek 2017)], 
Table 1 Homicide concentration

\begin{tabular}{|c|c|c|c|c|}
\hline Country & $\begin{array}{l}\text { City and population (in } \\
\text { millions) }\end{array}$ & $\begin{array}{l}\mathrm{n} \text { crimes (and rate } \\
\text { per } 100,000 \text { ) }\end{array}$ & $\begin{array}{l}\% \text { of streets accounting for } 25 \% \\
\text { of crime ( } n \text { streets) }\end{array}$ & $\begin{array}{l}\% \text { of streets accounting } \\
\text { for } 50 \% \text { of crime ( } \mathrm{n} \\
\text { streets) }\end{array}$ \\
\hline \multirow[t]{4}{*}{ Brazil } & Duque de Caxias (0.3) & 454 (133) & $0.4(42)$ & $1.1(126)$ \\
\hline & Nova Iguaçu (0.8) & $431(55)$ & $0.3(42)$ & $0.9(125)$ \\
\hline & Rio de Janeiro (6.3) & $1909(30)$ & $0.3(129)$ & $1.1(455)$ \\
\hline & São Gonçalo (0.3) & $439(130)$ & $0.2(22)$ & $1.0(102)$ \\
\hline \multirow[t]{4}{*}{ Colombia ${ }^{a}$} & Barranquilla (1.2) & $523(43)$ & $0.2(n a)$ & $0.7(n a)$ \\
\hline & Bogotá (8.1) & $1834(23)$ & $0.2(n a)$ & $0.5(n a)$ \\
\hline & Cali (2.4) & $2456(102)$ & $0.4(\mathrm{na})$ & $1.3(n a)$ \\
\hline & Medellin (2.5) & $1503(60)$ & 0.4 (na) & $1.2(n a)$ \\
\hline Venezuela ${ }^{b}$ & Sucre (0.3) & $223(74)$ & $0.4(\mathrm{na})$ & $1.5(n a)$ \\
\hline
\end{tabular}

a Mejía et al. (2015)

b Jaitman and Ajzenman (2016)

Numbers in bolditalic indicate values below Weisburd's (2015) bandwidths and numbers in italics indicate values above Weisburd's (2015) bandwidths. All data periods are for 2017 unless stated: Brazil 2016, Colombia 2012-2013, Venezuela 2014

Weisburd's bandwidths of crime concentration are the most used and allow for the best comparison against other results.

For each city, the number of crimes on each street segment was calculated, from which the number of street segments representing the cumulative proportion of $25 \%$ of crime and $50 \%$ of crime in each city was determined. The average length of street segments across the sample was $139 \mathrm{~m},{ }^{1}$ comparable to the average street segment length of $144 \mathrm{~m}$ in Weisburd's study (2015). Population statistics were sourced from each contributing agency and crime rates were calculated to allow for further examination of the results.

\section{Results}

Tables 1, 2, 3 and 4 show levels of crime concentration for homicides, robberies, theft from the person, other theft and vehicle theft. Overall, most results were within Weisburd's (2015) crime concentration bandwidths, albeit at the lower end of these bandwidths. Across all crime types and all cities the average proportion of streets accounting for $25 \%$ of crime was $0.8 \%$ and was $2.5 \%$ for the proportion of streets accounting for $50 \%$ of crime. The exception to this was homicide where the percentage of street segments containing crime concentrations were consistently below Weisburd's bandwidths, with all examples experiencing $50 \%$ of homicides in no more than $1.4 \%$ of street segments. In cities in Mexico vehicle theft concentration threshold levels were also reached by a proportion of segments that fell below Weisburd's bandwidths.
On examination of the tables, no apparent pattern was present that related crime concentration levels to population, the number of crimes nor the crime rate. ${ }^{2}$

\section{Implications and conclusions}

This study provides the first detailed crime specific account of crime concentration at micro-places in cities in Latin America. In most cases, threshold concentration levels were achieved towards the lower end of Weisburd's bandwidths, and several were below. The results suggest that crime is concentrated at higher levels in Latin American cities than in the western-industrialised contexts from which Weisburd proposed crime concentration bandwidths. Our results also support previous research (Chainey and Monteiro 2019) that indicates that differences in population, the volume of crime and crime rates do not appear to be related to differences in crime concentration in Latin American settings. Chainey and Monteiro (2019) suggest that crime concentration is more likely to be related to differences in the distribution of favorable conditions, determined by a combination of specific situational, offending site selection, and neighborhood conditions being present at very few places. Determining the extent of the contribution of each of these factors, and the differences between them in a variety of settings (e.g., comparing Latin American cities to cities in the United States) is a topic worthy of further research on why crime concentration levels vary.

Crime concentration levels were highest for homicide. Whilst homicides are typically considered to be a rare 
Table 2 Robbery concentration

\begin{tabular}{|c|c|c|c|c|}
\hline Country & City and population (in millions) & $\begin{array}{l}\mathrm{n} \text { crimes (and rate } \\
\text { per } 100,000 \text { ) }\end{array}$ & $\begin{array}{l}\% \text { of streets accounting } \\
\text { for } 25 \% \text { of crime ( } n \text { streets) }\end{array}$ & $\begin{array}{l}\% \text { of streets accounting } \\
\text { for } 50 \% \text { of crime ( } \mathrm{r} \\
\text { streets) }\end{array}$ \\
\hline \multirow[t]{11}{*}{ Argentina } & Almirante Brown (0.6) & $1509(271)$ & $1.1(157)$ & $3.6(505)$ \\
\hline & Campana (0.1) & $482(513)$ & $1.7(57)$ & $5.4(176)$ \\
\hline & Florencio Varela (0.4) & 837 (197) & $0.8(92)$ & $2.7(300)$ \\
\hline & General Pueyrredón (0.6) & $2033(360)$ & $0.6(203)$ & $1.9(626)$ \\
\hline & General Rodriguez (0.1) & $163(187)$ & $0.2(23)$ & $0.6(64)$ \\
\hline & La Plata (0.8) & $3837(502)$ & $1.2(298)$ & $3.4(861)$ \\
\hline & Lujan (0.1) & $246(230)$ & $0.8(32)$ & $2.3(93)$ \\
\hline & Merlo (0.5) & $1049(202)$ & $0.8(141)$ & $2.3(403)$ \\
\hline & Moreno (0.1) & $1652(1116)$ & $0.8(146)$ & $2.6(494)$ \\
\hline & Pergamino (0.1) & 1059 (1009) & $2.4(95)$ & $7.1(275)$ \\
\hline & Quilmes (0.5) & $2179(420)$ & $1.4(173)$ & $4.4(533)$ \\
\hline \multirow[t]{7}{*}{ Brazil } & Belford Roxo (0.5) & $2681(573)$ & $1.7(58)$ & $4.9(167)$ \\
\hline & Duque de Caxias (0.3) & $7938(2328)$ & $0.5(60)$ & $2.4(271)$ \\
\hline & Niteroi (0.5) & $4629(949)$ & $0.8(47)$ & $3.1(166)$ \\
\hline & Nova Iguaçu (0.8) & $8310(1055)$ & $0.4(59)$ & $2.2(255)$ \\
\hline & Rio de Janeiro (6.3) & $55,149(873)$ & $0.8(350)$ & $3.5(1384)$ \\
\hline & São Gonçalo (0.3) & $12,357(3667)$ & $1.0(78)$ & $3.7(320)$ \\
\hline & São João de Meriti (0.6) & $5293(885)$ & $3.3(51)$ & $10.5(165)$ \\
\hline Mexico & Mexico City (8.9) & $8369(95)$ & $0.2(330)$ & 0.9 (1509) \\
\hline Uruguay & Montevideo (1.4) & $8971(650)$ & $0.8(287)$ & $2.8(938)$ \\
\hline
\end{tabular}

Refer Table 1 footnote

Table 3 Theft (Argentina-other theft; Colombia - theft from the person) concentration

\begin{tabular}{llcll}
\hline Country & $\begin{array}{l}\text { City and population (in } \\
\text { millions) }\end{array}$ & $\begin{array}{l}\mathbf{n} \text { crimes (and rate } \\
\text { per 100,000) }\end{array}$ & $\begin{array}{l}\text { \% of streets accounting for 25\% } \\
\text { of crime (n streets) }\end{array}$ & $\begin{array}{l}\text { \% of streets accounting } \\
\text { for 50\% of crime ( } \mathbf{n} \\
\text { streets) }\end{array}$ \\
\hline Argentina & Bahia Blanca (0.3) & $869(316)$ & $0.6(86)$ & $2.2(301)$ \\
& Olavarria (0.1) & $192(171)$ & $0.7(34)$ & $\mathbf{1 . 7 ( 8 2 )}$ \\
& San Nicolas (0.1) & $318(237)$ & $0.7(32)$ & $2.2(107)$ \\
& Tandil (0.1) & $305(261)$ & $0.9(45)$ & $2.4(121)$ \\
& Zarate (0.1) & $373(377)$ & $0.7(29)$ & $2.4(101)$ \\
Colombia $^{a}$ & Barranquilla (1.2) & $8933(733)$ & $1.0(\mathrm{na})$ & $2.2(\mathrm{na})$ \\
& Bogatá (8.1) & $39,825(493)$ & $0.5(\mathrm{na})$ & $2.4(\mathrm{na})$ \\
& Cali (2.4) & $14,431(601)$ & $0.6(\mathrm{na})$ & $\mathbf{0 . 9 ( n a )}$ \\
\hline
\end{tabular}

Refer Table 1 footnote

event, in Latin American cities this is less the case. The conditions that give rise to areas becoming high homicide concentration areas may be the same conditions that create crime concentration areas for other crime types, and would be another topic worthy of further study.

To date, most programs to reduce crime in Latin America are applied at macro and meso levels and aim to address the structural determinants associated with crime such as social inequality and poverty (Bergman
2018; Inter-American Development Bank 2016), yet high crime levels persist. The results from the current study provide an indication of the opportunities for implementing programs that are targeted to the micro-place level in Latin American cities. The findings from the current study have already helped to inspire the piloting of hot spot policing and problem oriented policing programs in several of the cities that participated in the study, with initial evaluations reporting 
Table 4 Vehicle theft concentration

\begin{tabular}{|c|c|c|c|c|}
\hline Country & City and population (in millions) & $\begin{array}{l}\mathrm{n} \text { crimes (and rate } \\
\text { per } 100,000 \text { ) }\end{array}$ & $\begin{array}{l}\% \text { of streets accounting } \\
\text { for } 25 \% \text { of crime ( } n \text { streets) }\end{array}$ & $\begin{array}{l}\% \text { of streets accounting } \\
\text { for } 50 \% \text { of crime ( } n \\
\text { streets) }\end{array}$ \\
\hline \multirow[t]{4}{*}{ Argentina } & La Matanza (1.8) & $5160(291)$ & $0.5(165)$ & $2.3(723)$ \\
\hline & Lanus (0.5) & $2303(507)$ & $2.3(186)$ & $6.7(533)$ \\
\hline & Lomas de Zamora (0.6) & $2632(429)$ & $1.8(202)$ & $5.5(637)$ \\
\hline & San Martin (0.4) & $1635(387)$ & $2.1(162)$ & $5.9(467)$ \\
\hline \multirow[t]{4}{*}{ Colombia $^{a}$} & Barranquilla (1.2) & $1406(115)$ & $0.6(n a)$ & $1.9(n a)$ \\
\hline & Bogota (8.1) & $6573(81)$ & 0.4 (na) & $1.5(n a)$ \\
\hline & Cali (2.4) & $6442(268)$ & 0.7 (na) & 2.2 (na) \\
\hline & Medellin (2.5) & $9862(393)$ & 0.9 (na) & 3.0 (na) \\
\hline \multirow[t]{7}{*}{ Mexico } & Ecatepec (1.7) & $828(50)$ & $0.6(12)$ & $1.8(35)$ \\
\hline & Escobedo (0.4) & $281(80)$ & $0.2(46)$ & $0.5(115)$ \\
\hline & Monterrey (1.1) & $267(24)$ & $0.3(37)$ & $0.8(104)$ \\
\hline & Oaxaca (0.3) & $450(176)$ & $0.03(5)$ & $0.1(12)$ \\
\hline & Tlalnepantla (0.7) & $6216(952)$ & $0.8(145)$ & $2.1(383)$ \\
\hline & Tlaxcala (0.1) & $333(378)$ & $0.2(15)$ & $0.8(50)$ \\
\hline & Zacatecas (1.6) & $240(15)$ & $0.03(3)$ & $0.1(7)$ \\
\hline
\end{tabular}

Refer Table 1 footnote

reductions in crime (Alvarado and Muggah 2018; Chainey et al. 2018).

\section{Acknowledgements}

We thank Luciano de Lima Gonçalves and Victor Chagas Matos from the Rio de Janeiro Institute of Public Safety, and Isaias Aparicio Olivera Bordon and Angel Atilio Otero Fernandez from the Uruguay Police Crime Analysis Unit for supporting the research by helping to supply recorded crime data.

\section{Authors' contributions}

SPC was the main author of the publication and coordinated the supply of the results from each contributing author. GP generated and supplied the results for Argentina. ERV provided the results for Mexico City, and NOGR and JLHR worked with SPC to produce the results for all other cities in Mexico. JM worked with SPC to produce the results for all other cities in Brazil. SPC produced the results for Montevideo and sourced the results for all other cities. All authors read and approved the final manuscript.

\section{Funding}

No funding was provided for this research.
Availability of data and materials

The original crime records data used for this research cannot be publicly shared due its restricted content.

\section{Competing interests}

The authors declare that they have no competing interests.

\section{Author details}

${ }^{1}$ Department of Security and Crime Science, University College London, 35 Tavistock Square, London WC1H 9EZ, England, UK. ${ }^{2}$ Ministry of Security for the Province of Buenos Aires, Buenos Aires, Argentina. ${ }^{3}$ National Commission of Security, Mexico City, Mexico. ${ }^{4}$ Institute of Public Safety, Rio de Janeiro, Brazil.

\section{Appendix}

See Table 5. 
Table 5 Number of street segments and average street segment lengths

\begin{tabular}{|c|c|c|c|}
\hline Country & City & $\begin{array}{l}\mathrm{n} \text { of street } \\
\text { segments }\end{array}$ & $\begin{array}{l}\text { Average length } \\
\text { of street segment } \\
\text { (m) }\end{array}$ \\
\hline \multirow[t]{20}{*}{ Argentina } & Almirante Brown & 14,119 & 105 \\
\hline & Bahia Blanca & 13,915 & 134 \\
\hline & Campana & 3288 & 125 \\
\hline & Florencio Varela & 10,975 & 124 \\
\hline & General Pueyrredón & 32,494 & 126 \\
\hline & General Rodriguez & 10,081 & 158 \\
\hline & La Matanza & 31,583 & 101 \\
\hline & La Plata & 25,235 & 161 \\
\hline & Lanus & 7934 & 106 \\
\hline & Lomas de Zamora & 11,501 & 109 \\
\hline & Lujan & 4070 & 133 \\
\hline & Merlo & 17,750 & 102 \\
\hline & Moreno & 18,925 & 106 \\
\hline & Olavarria & 4778 & 127 \\
\hline & Pergamino & 3880 & 107 \\
\hline & Quilmes & 12,216 & 101 \\
\hline & San Martin & 7849 & 100 \\
\hline & San Nicolas & 4922 & 132 \\
\hline & Tandil & 5084 & 166 \\
\hline & Zarate & 4222 & 189 \\
\hline \multirow[t]{8}{*}{ Brazil } & Belford Roxo & 7752 & 143 \\
\hline & Duque de Caxias & 23,953 & 133 \\
\hline & Niteroi & 10,618 & 137 \\
\hline & Nova Iguaçu & 27,468 & 139 \\
\hline & Rio de Janeiro & 83,889 & 152 \\
\hline & São Gonçalo & 19,845 & 127 \\
\hline & São João de Meriti & 3318 & 123 \\
\hline & Belo Horizonte & 18,067 & 200 \\
\hline \multirow[t]{4}{*}{ Colombia } & Barranquilla & 21,545 & 154 \\
\hline & Bogotá & 137,117 & 118 \\
\hline & Cali & 49,658 & 124 \\
\hline & Medellin & 37,055 & 125 \\
\hline Mexico & Mexico City & 164,228 & 231 \\
\hline Uruguay & Montevideo & 33,975 & 117 \\
\hline Venezuela & Sucre & 1064 & 152 \\
\hline
\end{tabular}

Received: 18 January 2019 Accepted: 17 July 2019

Published online: 03 August 2019

\section{References}

Alvarado, N., \& Muggah, R. (2018). Crimen y violencia: un obstáculo para el desarrollo de las ciudades de América Latina y el Caribe. Documento para discussion IDB-DP-644. Inter-American Development Bank: Washington, D.C. Retrieved December 2, 2018 from https://igarape.org.br/crime-andviolence-obstacles-to-development-in-latin-america-and-caribbean-citie s.

Bergman, M. (2018). More money, more crime: Prosperity and rising crime in Latin America. New York: Oxford University Press.

Bernasco, W., \& Steenbeek, W. (2017). More places than crimes: Implications for evaluating the law of crime concentration at place. Journal of Quantitative Criminology, 33(3), 451-467.

Braga, A. A., Andresen, M. A., \& Lawton, B. (2017). The law of crime concentration at places: Editors' Introduction. Journal of Quantitative Criminology, 33(3), 421-426

Chainey, S., \& Monteiro, J. (2019). The dispersion of crime concentration during a period of crime increase. Security Journal. https://doi.org/10.1057/s4128 4-019-00165-x.

Chainey, S., Serrano-Berthet, R., \& Veneri, F. (2018). Evaluando el impacto del Programa de Alta Dedicación Operativa (PADO) en la reducción de robos violentos en Montevideo, Uruguay. ¿Cómo evitar el delito urbano?: el Programa de Alta Dedicación Operativa en la nueva Policía uruguaya. Washington DC: Inter-American Development Bank and Uruguay Ministry of Justice.

Fórum Brasileiro de Segurança Pública. (2011). Anuário brasileiro de segurança pública. São Paulo: Fórum Brasileiro de Segurança Pública.

Inter-American Development Bank. (2016). Violent crime in Latin American cities. Discussion paper number IDB-DP-474. Washington, D.C.: IDB. Retrieved October 4, 2017 from https://publications.iadb.org/handl e/11319/7821.

Jaitman, L., \& Ajzenman, N. (2016). Crime concentration and hot spot dynamics in Latin America. Inter-American Development Bank: Washington, D.C.

Lee, Y., Eck, J. E., SooHyun, O., \& Martinez, N. (2017). How concentrated is crime at places? A systematic review from 1970 to 2015. Crime Science, 6(6), $1-16$.

Mejía, D., Ortega, D., \& Ortiz, K. (2015). Un análisis de la criminalidad urbana en Colombia. Documento de Trabajo CAF: Caracas.

Ratcliffe, J. H. (2004). Geocoding crime and a first estimate of a minimum acceptable hit rate. International Journal of Geographical Information Science 18(1), 61-72.

UNODC. (2018). United Nations Office on Drugs and Crime Statistics Online. Retrieved December 10, 2018 from https://data.unodc.org/.

Weisburd, D. (2015). The law of crime concentration and the criminology of place. Criminology, 53, 133-157.

\section{Publisher's Note}

Springer Nature remains neutral with regard to jurisdictional claims in published maps and institutional affiliations.

Ready to submit your research? Choose BMC and benefit from

- fast, convenient online submission

- thorough peer review by experienced researchers in your field

- rapid publication on acceptance

- support for research data, including large and complex data types

- gold Open Access which fosters wider collaboration and increased citations

- maximum visibility for your research: over $100 \mathrm{M}$ website views per year

At BMC, research is always in progress.

Learn more biomedcentral.com/submissions 